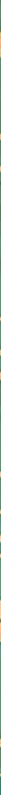

Routledge Studies in Twentieth-Century Literature

\title{
BRINGING UP WAR BABIES
}

THE WARTIME CHILD IN WOMEN'S WRITING AND PSYCHOANALYSIS AT MID-CENTURY

Amanda Jane Jones

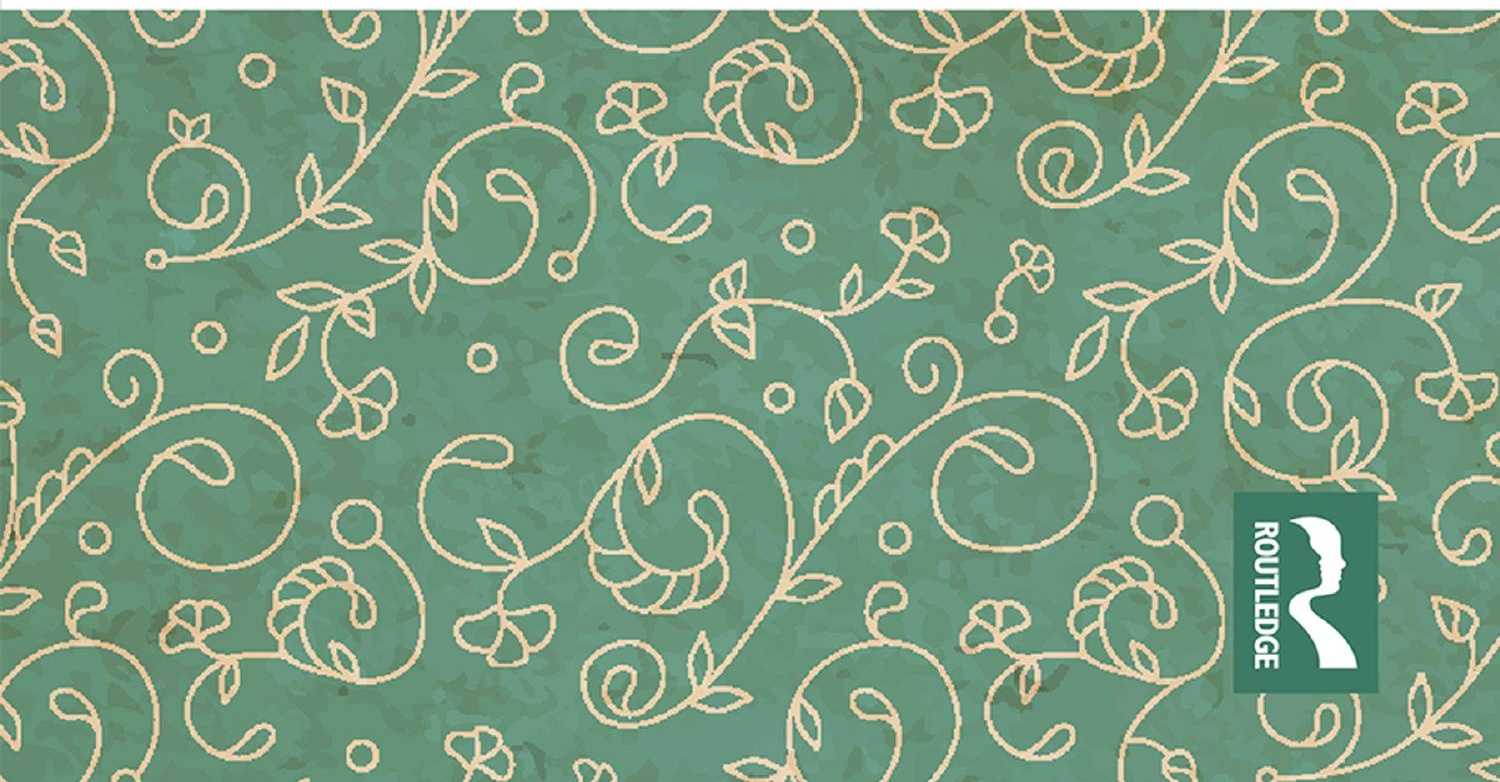




\section{Bringing Up War Babies}

The figure of the wartime child in the mid-twentieth century unsettles and disturbs. This book employs a range of material - biographical, literary and historical - to chart some of the surprising and unanticipated crossovers between women's writing and early psychoanalysis in the years of the Second World War and the decades before and after. This volume includes examples of children's adventure fiction, as well as works written for adult audiences, and important and previously unrecognized similarities are noted.

The war was a disruptive influence in the lives of all who lived through it. Although active self-censorship is observed in the behaviour and attitudes of adults at this time, this book demonstrates how fictional children are able to articulate feelings such as anxiety and fear that adults were under pressure to conceal or to repress, and at times, the figure of the wartime child becomes a surrogate for the writer herself or her suppressed fears and anxiety. When peace returned, this study finds women writers quick to identify and communicate a discomfiting new ambivalence between parents and children.

Amanda Jane Jones was awarded a PhD in English Literature by Anglia Ruskin University in 2015. She has written several articles that focus on middlebrow literature and psychoanalytic theory, children's literature and women's writing. She also writes fiction. 


\section{Routledge Studies in Twentieth-Century Literature}

\section{The Nature of Modernism}

Ecocritical Approaches to the Poetry of Edward Thomas, T. S. Eliot, Edith Sitwell and Charlotte Mew

Elizabeth Black

7 Nonlinear Temporality in Joyce and Walcott History Repeating Itself with a Difference

Sean Seegar

8 Writing for the Masses

Dorothy L. Sayers and the Victorian Literary Tradition Christine Colon

9 Essays on Music and Language in Modernist Literature Musical Modernism

Katherine O'Callaghan

10 Ulysses and Faust

Tradition and Modernism from Homer till the Present Harry Redner

11 Lorca's Legacy

Essays in Interpretation

Jonathan Maybew

12 The Early Avant-Garde

Literature and Art 1900-1925

Willard Bohn

13 Bringing Up War Babies

The Wartime Child in Women's Writing and Psychoanalysis at Mid-Century

Amanda Jane Jones

For a full list of titles in this series, please visit www.routledge.com. 


\section{Bringing Up War Babies The Wartime Child in Women's Writing and Psychoanalysis at Mid-Century}

\section{Amanda Jane Jones}

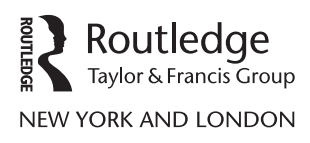


First published 2018

by Routledge

711 Third Avenue, New York, NY 10017

and by Routledge

2 Park Square, Milton Park, Abingdon, Oxon OX14 4RN

Routledge is an imprint of the Taylor \& Francis Group, an informa business

(C) 2018 Taylor \& Francis

The right of Amanda Jane Jones to be identified as author of this work has been asserted by her in accordance with sections 77 and 78 of the Copyright, Designs and Patents Act 1988 .

All rights reserved. No part of this book may be reprinted or reproduced or utilised in any form or by any electronic, mechanical, or other means, now known or hereafter invented, including photocopying and recording, or in any information storage or retrieval system, without permission in writing from the publishers.

Trademark notice: Product or corporate names may be trademarks or registered trademarks, and are used only for identification and explanation without intent to infringe.

Library of Congress Cataloging-in-Publication Data

Names: Jones, Amanda Jane, author.

Title: Bringing up war babies: the wartime child in women's writing and psychoanalysis at mid-century / by Amanda Jane Jones.

Description: New York: Routledge, 2018. I

Series: Routledge studies in twentieth-century literature; 51।

Includes bibliographical references and index.

Identifiers: LCCN 2018007723

Subjects: LCSH: Children's literature, English-History and criticism. I

English literature-Women authors-History and criticism. I

English literature-20th century-History and criticism. I

World War, 1939-1945-Literature and the war. I Psychoanalysis and literature-Great Britain. I Children in literature. I

War in literature. I Anxiety in literature. I Parenthood in literature.

Classification: LCC PR990 .J57 2018 I DDC 820.9/3581-dc23

LC record available at https://lccn.loc.gov/2018007723

ISBN: 978-1-138-50076-1 (hbk)

ISBN: 978-1-315-14398-9 (ebk)

Typeset in Sabon

by codeMantra 
For my parents, Mike and Christine And for Chris, Hattie and Walter

With my love and gratitude. Always. 


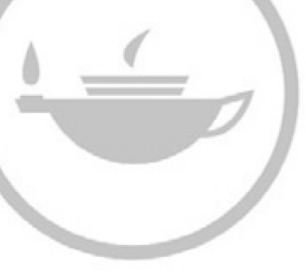

Taylor \& Francis Taylor \& Francis Group

http://taylorandfrancis.com 


\section{Contents}

List of Figures ix

Acknowledgements $\quad$ xi

Introduction 1

1 Adventures and Analysis: Anxiety, Danger and Psychoanalysis in Three 1940s Children's Adventure Novels

2 Containment and Mothering 53

3 Social Reform, Welfare and the Child at Mid-Century 91

4 Evacuation and Enuresis: The Chameleon Child 116

5 Literary Mothers $\quad 140$

6 Postwar Parenting and Ambivalence 176

$\begin{array}{ll}\text { Conclusion } & 210\end{array}$

Bibliography $\quad 217$

Index 235 


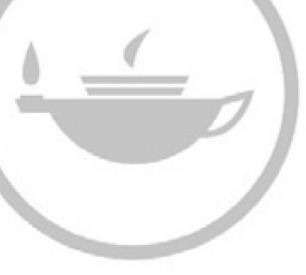

Taylor \& Francis Taylor \& Francis Group

http://taylorandfrancis.com 


\section{List of Figures}

I.1 IWM D 6160 At the Foster Parents Plan London nursery, Phyllis Terry, aged two years two months, puts her teddy to bed while her friend Peter looks on. According to the original caption, Phyllis slept in an underground shelter all winter. Ministry of Information Second World War Official Collection, Imperial War Museum

I.2 Mother crouches with children in an underground shelter. Toni Frissell Collection, Library of Congress. LC-F9-02-4501-028A

1.1 IWM D 17277 Doreen, Susie and Hugh Buckner play 'wardens' in their home in London. Doreen, Susie and their dolls sit in an upturned armchair covered in blankets, as 'Warden' Hugh checks they are safely inside their make-believe air-raid shelter. Ministry of Information Second World War Official Collection, Imperial War Museum

2.1 IWM D 16849 Van Girl: Lilian Carter is greeted by her son Clarence as she returns home after a day's work delivering goods for the LMS Railway Company. Clarence was named after his father who is in the Army and has yet to meet his son. Ministry of Information Second World War Official Collection, Imperial War Museum

2.2 Bovington Tank Museum. 0867-A4 Mark IV female, G Battalion G46 'Gina' Kitchener's Wood, 1st August $1917 \quad 60$

2.3 Bovington Tank Museum. 1546 C1 Mark IV blown apart

2.4 Mother and two children viewed in shelter. Toni Frissell Collection, Library of Congress. LC-F9-02-4501-027A

3.1 Boys wander about a bombsite in the aftermath of an air raid. The Toni Frissell Collection, Library of Congress. LC-F9-4501-023A 
3.2 IWM D 6124 Some nurses and children say goodbye to Eric Muggeridge, Organizing Director of the Foster Parents Plan, as he drives away in an ambulance car that it taking some children to another home in the countryside. Ministry of Information Second World War Official Collection, Imperial War Museum

4.1 IWM D 824 A group of smiling evacuees with gas mask boxes hold hands on a walk in Reading during 1940. These boys and girls were originally from the Galleywall Road area of Rotherhithe in Kent

4.2 IWM D 2229 Ted Rickson, an evacuee from Kennington in London, sits with his arm around Moira, the Irish Wolfhound, on the grass outside Dartington Hall near Totnes, South Devon in 1941. Ministry of Information Second World War Official Collection, Imperial War Museum, London

4.3 IWM D 21120 Boy stands in cot to say goodnight. He is at a nursery school at The Old Manor House, Wendover Buckinghamshire. Ministry of Information Second World War Official Collection, Imperial War Museum, London

5.1 Line map showing the correspondence connections between wartime writers. Created using MindNode application

5.2 Image of Heinz Halberstadt, Anna Freud and W. Ernst Halberstadt. The Freud Museum, London

6.1 IWM D 1303 A young boy named Leslie plants a flag into the ruins that are all that is left of his home after an air raid in 1940. Ministry of Information Second World War Official Collection, Imperial War Museum, London

C.1 Photograph taken by Toni Frissell entitled 'Abandoned Boy (Without Elephant)'. According to Toni Frissell Photographs 1933-1967, edited by George Plimpton and Sidney Frissell Stafford (1994), this young boy returned from playing to find his house had been hit by a V2 rocket and his parents and brother killed inside. He sits in the ruins that were his home. He grew up to become a truck driver, and when IBM used one of the photographs to illustrate an exhibition, he recognised his picture. The Toni Frissell Collection, Library of Congress. LC-F9-02-4501-022 


\section{Acknowledgements}

At outset, I wish to thank Michelle Salyga, Tim Swenarton and all at Taylor \& Francis and Assunta Petrone of codeMantra for publishing this book and for their kind and helpful comments as they guided this work from proposal to publication. Thanks too to the anonymous reader for positive and encouraging comments.

I thank also Anglia Ruskin University for its generous award of a feesonly three-year PhD studentship, which helped to make the PhD at the origin of this study financially possible. I am also very grateful for the guidance and direction of my supervisory team, expertly led by Professor Mary Joannou, who has patiently read and advised upon countless drafts at all stages of my study. Without her patient and astute advice, this book might never have come about, and I thank her wholeheartedly.

In addition to the above-named individuals and organizations, I wish to extend my thanks to the staff of the King's College Archive Centre, Cambridge, for help in accessing Rosamond Lehmann's papers and to the British Library staff for their assistance with the papers of Phyllis Bottome. I thank the Tank Museum at Bovington, the Freud Museum, Hampstead and the Imperial War Museum, London for their kind permission to use the images included herein and the Library of Congress for their assistance with the images of Toni Frissell. Sincere thanks are due also to Bill Streatfeild for generously allowing me to access and use his aunt Noel's private papers, which inform and contribute to all six chapters and which also were the source for my two Women's History Magazine articles, in 2011 and 2015. I wish also to express my gratitude to my colleagues at the Churchill Archives Centre, Churchill College Cambridge for their encouragement and support in the final stages of bringing this book to press.

I thank my late cousin (once removed!) Barbara Hardy for her encouragement and for her incisive contributions to drafts of my $\mathrm{PhD}$.

Heartfelt thanks are more than due to my family. I send my love and sincere gratitude to my parents and especial thanks to my mother for her patience in reading many drafts of this book. Lastly, I thank my dear husband Chris and our children, Hattie and Walter, for their support and love and for sticking with me and allowing me this precious opportunity to write. 


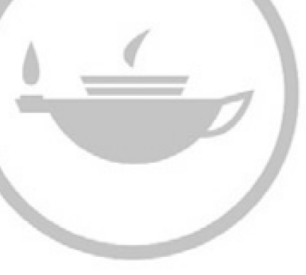

Taylor \& Francis Taylor \& Francis Group

http://taylorandfrancis.com 


\section{Introduction}

The subject of this book is the child's experience of war as represented in novels and short stories written by women in the years 1930-60. I address work by the writers Noel Streatfeild, Margaret Lovett, Mary Treadgold, Phyllis Bottome, Elizabeth Bowen, Elizabeth Taylor, Rosamond Lehmann, Rose Macaulay, Winifred Peck, Rumer Godden and Ruth Adam. No previous book, to the best of my knowledge, has examined the perspective of the child in wartime in middlebrow women's fiction. In order to address significant gaps in existing knowledge, my work focuses in part on the question of anxiety, as this affects writing for and about children during the war as well as on the child's experience of evacuation. Both middlebrow writing and psychoanalysis are often criticized for being middle-class in focus and sense of family and background, yet until now these similarities have gone largely unnoticed. Therefore, this book offers the first sustained application of psychoanalytic theories to middlebrow women's fiction. ${ }^{1}$

This book does not debate the case for or against psychoanalysis but instead identifies unexpected, and at times disturbing, echoes and preechoes of psychoanalysis in the texts that middlebrow women were writing about children in the 1930s to 1950 s and shared concerns between early exponents of psychoanalysis and these writers.

The literary-historical period under discussion includes works from the decades before and after 1939-45 because earlier and later works of fiction are part of the collective engagement with the psychological realities and legacies of war. Anyone over the age of thirty-five in 1939 (which includes most of my selected writers) would have memories of the First World War. As Bowen writes in 'Panorama of the Novel' (1944), 'between 1930 and 1939, writers reluctantly faced the next war instead of trying to escape the previous one' (141). As Kate McLoughlin states in The Cambridge Companion to War Writing (2009), 'war reverberates through literature' (1), and these writers illustrate some of these reverberations. It closes with a study of some of the war's after effects, as in a postwar period of increased austerity, women were still communicating damaged childhoods and difficult family reconciliations in the fiction of the 1950s. 


\section{Introduction}

In these troubled times, psychoanalysis had 'very real implications for public debate and social policy', as Michal Shapira shows in The War Inside: Psychoanalysis, Total War, and the Making of the Democratic Self (2013) (5). ${ }^{2}$ This book demonstrates how psychoanalysis, and theories about anxiety in particular, such as Freud's 'Inhibitions, Symptoms and Anxiety' (1926) and Klein's 'Love, Guilt and Reparation' (1937), are illuminating in relation to wartime women's fiction about children, written for both children and adults. It is significant that many psychoanalysts of the period were focusing on the analysis of children and on the importance of childhood to the development of the adult and that they drew important comparisons between the war and what was going on inside the child's mind. Many of the early psychoanalysts working with children in war-time Britain were women. 'England, Freud felt confident', would 'welcome his science eventually' due to its 'strong sense of the practical and the passionate love of justice', as Sally Alexander writes in 'Psychoanalysis in Britain in the Early Twentieth Century: An Introductory Note' (1998), adding that 'He might also have added the interest of emancipated women' (137). Melanie Klein, Anna Freud, Melitta Schmiderberg, May Sinclair and Susan Isaacs are examples of note. It is a fair criticism to accuse this new 'science' of being predominantly middle class, as almost every one of the analysts to whom this book refers was middle class. Moreover, many of the famous children in analysis were also the children of other, similarly middle-class psychoanalysts. Freud analysed his own daughter Anna as well as his grandson Ernst, while Klein did the same for her children and for the wife and children of Ernest Jones. The middlebrow women whose work I discuss shared significant cultural and socio-economic ideas and values with these middle-class analysts.

Women's middlebrow fiction anticipates and plays with a wide range of complex psychoanalytic theories other than the more notorious theories of Freud's, such as the Oedipus complex and his work on recovered memory, both well known and still controversial at the time. There are many good reasons why women found specific theories and theorists useful in exploring the psychoanalytical concerns that they did in their fiction, including their personal responses to anxiety and the desire to find a voice for painful wartime experiences, particularly in relation to motherhood.

The voices of women were key to British child analysis in the 1930s1950s, and I have chosen two second-generation woman psychoanalysts, Anna Freud and Melanie Klein, because their voices were central to the wartime debate on infant and child care and child anxiety within the British psychoanalytic community and because both lived and worked with children in Britain during the war (Figure I.1). ${ }^{3}$

Klein moved to London in 1926 at the invitation of Ernest Jones, where she analysed a number of the children (and wives) of her colleagues at 


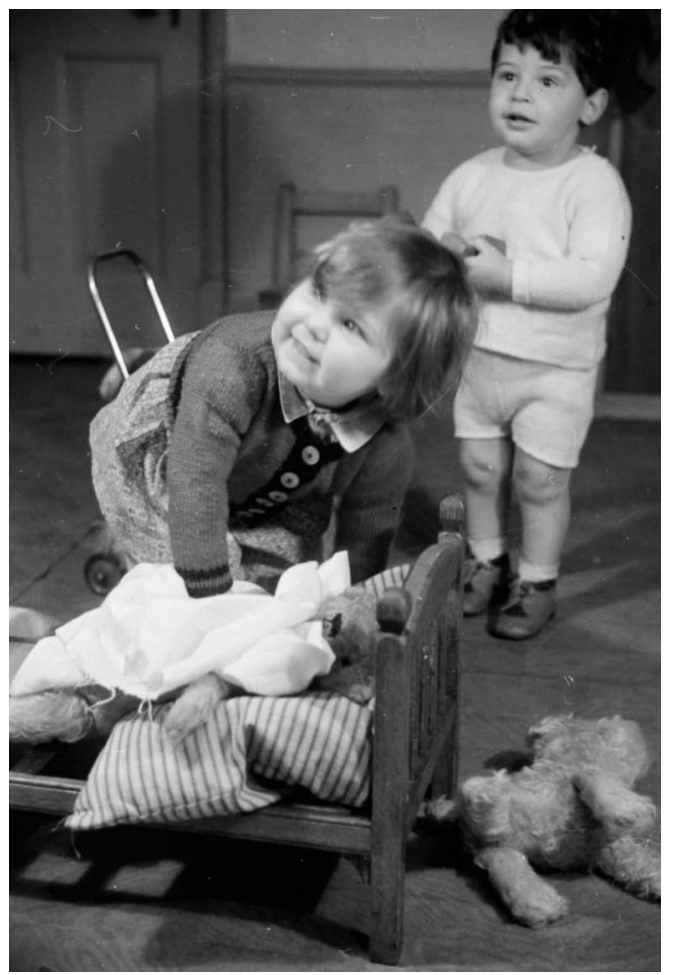

Figure I.1 IWM D 6160 At the Foster Parents Plan London nursery, Phyllis Terry, aged two years two months, puts her teddy to bed while her friend Peter looks on. According to the original caption, Phyllis slept in an underground shelter all winter. Ministry of Information Second World War Official Collection, Imperial War Museum.

the British Psychoanalytic Society. Her wartime analysis of 'Richard' at Pitlochry in 1940-1 (posthumously published as Narrative of a Child Analysis in 1961) is famous for its length and detail, covering over 450 pages. I refer to several of Klein's theories, but my primary works are 'Love, Guilt and Reparation', 'Narrative of a Child Analysis' and also 'Weaning' (1936). The influence of Klein permeates many of my writers and informs several chapters in which her ideas on the role of the mother are important. My second analyst, Anna Freud (the youngest daughter of Sigmund Freud) worked with children in Vienna and came to live in London with her father when they escaped from occupied Austria. ${ }^{4}$ She ran a residential nursery in Hampstead through the war years and wrote about its residents with her friend and colleague Dorothy Burlingham. I refer to a number of her works, including those in which she wrote collaboratively (with Burlingham): Young Children in Wartime in a 


\section{Introduction}

Residential War Nursery (1942), Infants Without Families: The Case For And Against Residential Nurseries (1944) and others she wrote on her own including 'The Concept of the Rejecting Mother' (1954), 'An Experiment in Group Upbringing' (1951) and 'About Losing and Being Lost' (1953). These publications constitute important resources to which reference is made in more than one chapter. During the war, Burlingham and Anna Freud's residential war nursery provided wartime homes for children whose family life had been 'broken up' (11) by war. ${ }^{5}$ These children were deprived of 'the natural background for their emotional and mental development' (11). As Michal Shapira observes in The War Inside, the Hampstead nursery offered 'unique care' (66) in a context that was simultaneously informed by, and informing, child war psychoanalysis. Shapira goes on to say that, with the exception of Klein's wartime theory, no 'other account of the connections between anxiety, aggression, war and the child' was as thorough as the work of Burlingham and Anna Freud. Shapira does not refer explicitly to literature.

However, Gill Plain, in Literature of the 1940s: War, Postwar and 'Peace' (2013), identifies three of my key texts as 'emerging' (55) from the context of Freud and Burlingham's fragmented and dis-located families, namely Streatfeild's Saplings, Bottome's London Pride and Noble's Doreen. The work of Anna Freud and Klein and their supporters forms a connective between the individual chapters of this book, as they contributed to studies of evacuation and post-war welfare as well as to much that went on in between.

Not all the analysts referred to here are women. I include some of Freud's theories, including 'The Creative Writer and Daydreaming' (1907), 'Beyond the Pleasure Principle' (1922), 'Inhibitions, Symptoms and Anxiety' (1926) and Wilfred Bion's containment theory of the 1950s. These discuss aspects of child development and the legacy of parental influence and how fear and anxiety are communicated. Many writers including Streatfeild, Treadgold, Bottome, Bowen, Lehmann, Macaulay, Peck and Adam reached similar conclusions to those of the analysts, although at times their fiction tested the limits of psychoanalytic theory.

\section{The Historical Setting}

The majority of my fictional works were first published between 1938 and 1948, and my discussion of this fiction takes full account of a number of major and varied reappraisals of the experience of the Second World War and its impact on men, women and children. ${ }^{6}$ This historical period saw considerable societal changes, especially for children growing up on the 'home front'. The long-term effects of modern warfare were familiar to those old enough to remember the First World War, when some eighteen air raids were carried out on the United Kingdom by 128 aeroplanes, which dropped about 300 tonnes of bombs and killed 
1,413 people. A total of 4,820 casualties are cited by Richard Titmuss in his Problems of Social Policy (1950). ${ }^{7}$ But the effects of this earlier war were sometimes more subtle and troubling. By 1939, 'some 120,000 British ex-servicemen had received final awards for primary psychiatric disability or were still drawing pensions - about $15 \%$ of all pensioned disabilities - and another 44,000 ... were getting pensions for "soldier's heart" or Effort Syndrome', according to Ben Shepherd's A War of Nerves: Soldiers and Psychiatrists 1914-1994 (2000) (144).

There had also been more recent air raids on Spanish towns and cities, including the bombing of Guernica (1937) memorialized by Picasso, in the Spanish Civil War in 1936, as well as the raids of 16-18 March 1938 on Barcelona. All contributed to a widespread fear that in a new war, early and widespread bombing raids would give rise to mass panic, and anxieties were expressed about the possibility of extensive public disorder. John Langdon-Davies's Air Raid: The Technique of Silent Approach, High Explosive Panic (1938) records the effect of the bombing raids in Barcelona in 1938. Such materials contributed to the government's decision in 1939 to evacuate children, the elderly and pregnant women out of areas deemed at great risk of attack before the outbreak of hostilities. Langdon-Davies writes that the Air Raid Precautions (ARP) 'folklore' seems to have come from 'somebody's inner consciousness' (65). One of my novelists, Streatfeild, was disturbed by the 'horrors' she was 'taught to expect' as part of her training as an ARP warden in 1938 (Bull 157).

In anticipation of 'horrors' to come and for the first time in the history of the United Kingdom, a state-run programme of evacuation encouraged the separation of families and the removal of children from the age of five (and sometimes younger) from their mothers and homes. The families to whom they were sent in the countryside were strangers; the selection of foster homes and the provision of education to evacuees were haphazard at best, with no provision of schooling for the many of the children who stayed at home (or returned to towns and cities). ${ }^{8}$ In her unpublished wartime diary for 1940, Streatfeild laments the 'effect of no schools on the children' on 3 September 1940, a year after the outbreak of war. ${ }^{9}$ There were many private arrangements for evacuation made in addition to the sinisterly named 'Operation Pied Piper'. According to Raynes Minns's Bombers and Mash: The Domestic Front 1939-45 (1980), the unprecedented conscription of women in 1941 under the National Service Act (No. 2) 1941 led to an estimated ' $90 \%$ of single women and $80 \%$ of married women with children over fourteen' being employed by the summer of 1943 (32-3). The war created considerable demand for childcare, even though women with responsibilities for children under fourteen were, in theory, exempt from war service. Bottome's novel London Pride (1941) discusses some of the challenges faced in finding suitable childcare for the under-fives. Mrs Barton sends 


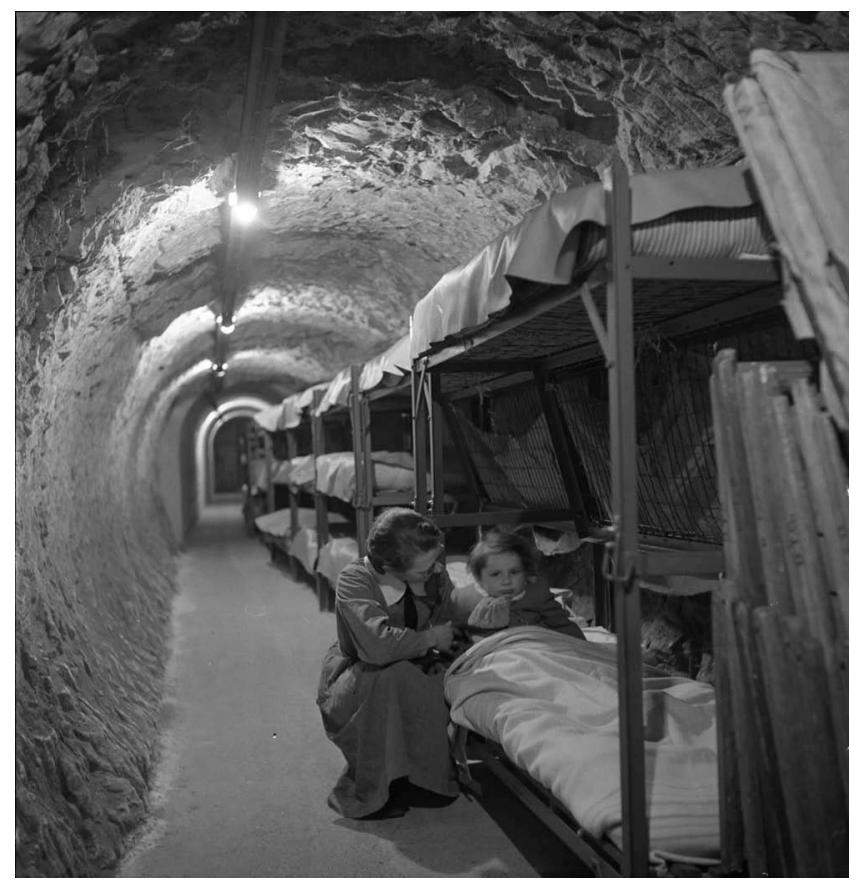

Figure I.2 Mother crouches with children in an underground shelter. Toni Frissell Collection, Library of Congress. LC-F9-02-4501-028A.

her daughter Mabel to a 'grimy' lady while she cleans houses (16) but considers sending her to a nursery (197). The continuing public interest in wartime children and evacuee stories can be seen in a range of published factual works on the subject, such as John Welshman's Churchill's Children (2010) and Julie Summers's When the Children Came Home: Stories of Wartime Evacuees (2012) (Figure I.2).

\section{'A War in the Mind'10}

Adam Piette's Imagination at War: British Fiction and Poetry 1939-1945 (1995) describes with feeling the 'consequences of wartime isolation on the private imagination' in what is 'less a study of the war itself than a study of the war in the mind' (1). He argues that the 'witness' of dissenting voices has been 'obscured' (1) and seeks to 'allow as many voices on stage as possible, contradictory and wavering as many of them are', yet the majority of these voices are male and generally produced outside the domestic sphere (1).

This book arrives at many of the same conclusions as Piette, but it is based on a quite different set of texts and writers' work. There are two 
kinds of war 'stories' that he identifies: the first coming from 'the stories the nation liked to tell itself' about bravery, courage and steadfast resilience and the second arising from contemporary texts and the stories he heard as a child about his family in the war, which is 'the inside story' of the war. He argues that both versions are true, but his 'private' story of the war, and the other narratives, are both 'condemnatory of British wartime culture'.

Middlebrow fiction records and subverts popular expectations of war stories. As one example, when Mrs Brown, a bombed-out woman in Streatfeild's A Table For Six (1942), declares that 'Each of us struggles in our own way to maintain those few things which will keep us sane and prop up our morale in this ghastly war' (31), the conventional 'war stories' in which hard work and self-sacrifice are desiderata are subtly undermined. In A Table for Six, the charity 'Comforts for the Bombed' is staffed by women who 'had not the face to be doing nothing for their country' (12) but 'dreaded the really efficient organizations' (12) that expected them to 'turn up' or face 'nasty questions' (12). Middlebrow writing has an important function in making complex issues familiar to its readership. Authors aim to bridge the gap between highbrow theories and the middle classes with humor or seriousness, as the case might be. For example, Laura, the heroine of E.M. Delafield's The Way Things Are, wakes to 'an intolerably lively, if scientifically inaccurate' recollection of 'the less pleasing' of 'Herr Freud's theories as to the nature of dreams' (152). The pioneering dissemination of knowledge can also be seen in Enid Bagnold's The Squire (1938), where Bagnold describes pregnancy and childbirth in frank and intimate terms, while Lehmann discusses morning sickness and backstreet abortions in The Weather in The Streets (1936). These women novelists discuss previously taboo subjects such as childbirth (and death) as well as parent-child relations with openness and honesty, challenging the socially sanctioned 'war stories' and many of the prevalent assumptions about childhood in and after the Second World War.

War disorientates and disrupts, and Piette shows how the 'many theatres of the Second World War hollowed and emptied out the private mind, transforming it into a scene of lies, artificial dreams and fabricated emotions' (4). The women writers with whom I am concerned describe scenes of domestic tragedy and, very often, children were amongst the unwilling performers in the midst of one of these 'theatres' of war, the home front.

Like Piette, I argue that war is brutal and that this war had particularly devastating effects on children. ${ }^{11}$ I acknowledge that these conclusions are not without precedent, but the particular women I write about all lived by what Piette calls the writer's duty to tell the truth:

It is one of the writer's duties to tell future generations what it was like to have a sensitive, inquiring intelligence during the times he 


\section{Introduction}

or she lived through. This responsibility becomes a terrible burden during wartime, but it was a burden many writers took up willingly. This book is based upon their witness.

The 'sensitive, inquiring intelligence' (4) of Streatfeild, Lovett, Treadgold, Bottome, Bowen, Taylor, Lehmann, Macaulay, Peck, Godden and Adam enables them to produce fiction that investigates and communicates the experience of war from a (primarily) middle-class background. While Piette focuses on the male voices of the war, I look at the domestic chaos of the broken wartime home and its influence on the youngest of victims and how women communicate their opinion of wartime childhoods and the burden of being witness to war with a kind of 'self-watching censorship' (Piette 2).

As Jago Morrison suggests in Contempory Fiction (2003), the novelist is subject to 'a demand for moral responsibility' (11) and feels she must 'respond anew to the paradoxical demands of history' (11) whilst also living with 'the weight and mass of events' (11). War is inevitably shocking to many of those who inadvertently find themselves caught up in it, and in some cases, writers bear witness to terrible personal suffering. The advent of a 'domestic front' in wartime broadens the range of people with firsthand knowledge and experience of war beyond combatants. Streatfeild saw 'something very nasty' which she 'would have been very glad' to have missed in south London while working as a volunteer on 14 September 1940 (the Diary). Her reticence on this occasion (a diary typescript was intended for publication) conceals precisely what she saw, but in many cases, an author's concentration upon the figure of the child, and sometimes on the fictional child's experiences and reactions, exposes more about the writer themselves than may have been intended. And on occasion, the primary material of the literary text is supported (as in the case of Streatfeild's typescript diary) by personal papers, including letters and diaries, all of which contribute to the writer's evidence as a witness to war.

Public expression of one's private feelings, or of doubts or fears about the progress of the war, were viewed as unpatriotic and shameful: the priority was to keep up an appearance of normality, whatever the circumstances, as war and war propaganda invaded homes and minds across the country. 'Grief seems to be strangely absent', and there is a sense that 'public grief would have been unpatriotic, feminine, weak', as Jenny Hartley writes in Hearts Undefeated: Women's Writing of the Second World War (1994) (7). The fiction I discuss shows children expressing grief and extreme distress, while their mothers and caregivers are denied a voice for the same pain. The containment of feelings comes at a considerable personal cost, as 'many suppressed their state of shock in order to keep going until the end of the war', suggests Raynes Minns in Bombers and Mash: The Domestic Front 1939-45 (1980) (187). 
As Piette puts it in Imagination at War, 'private suffering is humbled, rendered immaterial and anachronistic as a ghost, frightened into submission by the authentic horror of the mutilations taking place in Europe and in the news' (162). Moreover; 'wartime propaganda tempted writers to be falsely suspicious and cynically knowing so as to be two steps ahead of it, but the very way this was done caught their imaginations in a propaganda trap of forensic thought' (161). This theme of suppressed feelings is one that I return to on many occasions, as it echoes insistently throughout women's writing about children. The need to investigate and find an acceptable mode of articulating fear and anxiety gives greater significance to personal writing, which shows 'how far the public realm, in the form of press and news, had invaded, occupied and preoccupied private minds, creating an atmosphere of suspicious resistance to being duped, partly to keep the mind from being swamped' (163).

The intrusion of war into the home is matched by an invasion of the mind, but this book will show that some women at least were using their writing as a defensive tactic against the dual barrage of official propaganda and the bombs. Faced with the 'overbearing civic imperatives' (Piette 156) of propaganda, the threat of aerial bombardment makes infants of all: it places the individual in the position of the baby, vulnerable to the 'ungentle' mechanics of war, power and authority.

\section{War Studies and Psychoanalysis}

There is a long history of publication about the engagement between the mind, trauma and war, written from a range of perspectives from the poets of the First World War, to the accounts of post-traumatic stress communicated by veterans of later conflicts. ${ }^{12}$ Lyndsey Stonebridge's The Writing of Anxiety: Imagining Wartime in Mid-Century British Culture (1997) focuses on the war years and finds that there was much to be anxious about at the time. Stonebridge establishes the link between the wartime writer and the psychoanalyst's anxious baby. Speaking of the evacuee, she writes that 'these war children articulate the disorientation of wartime existence' but that they also 'become a sort of working metaphor for the anxiety of trying to imagine a world at war' (9 and 33). In The Writing of Anxiety, the child is also an agent for the writer, trying to understand 'what it means for the psyche to be shaped by a history that it cannot assimilate' (14). I take this proposition further: if the baby is what we become when we are truly at the mercy of fear, then writing about childhood offers an outlet for expressing what would otherwise remain as unarticulated wartime anxiety.

When the war ended, there was a long period of readjustment, with the gradual demobilization of the armed services and continuing austerity. Many homes and family ties had been badly damaged, and for those suppressing shock, unhappiness and grief, the return to peace accentuated the extent of their losses. 


\section{Introduction}

\section{The Child in the Wartime Novel}

It is not only women whose writing dwells on the child. In The Novel Since 1939 (1946), Henry Reed observes that in the seven years to 1946, 'almost every important English writer at the moment' had written on 'the theme of childhood' (23). Reed argues that the 'reason is perhaps to be sought in the growing acceptance of the importance which is attached to childhood and infancy by psychology'. Reed refers to Lehmann's The Ballad and the Source (1944) (22-3) and then considers Joyce Carey, L.P. Hartley and Forrest Reid in support of his arguments. He writes that 'in a world of darkness we learn to hug that memory of comparative light' and, he claims, 'a child may be unhappy but it is never wholly so; its happiness is not the mere absence of pain; and it has an innocence which the happiness of adult life is too complex to have' (23). He adds that 'it is natural to turn and attempt to recapture and understand and detail that lost possibility of Eden' (23). The authors with whom he is concerned (mostly men) differ significantly from the fiction of their female counterparts. The remembered 'Eden' of Reed's imaginary childhoods is remote from the childhoods in the children in the literary texts I discuss, as is the 'microcosm of the adult world' (25) seen in the work of L.P. Hartley and others. In contrast, my chosen writers observe and represent a child's world and investigate the child's interaction with the mother, rather than presenting a variant of the adult world. Betty Miller's On the Side of the Angels (1945) is alive to the 'undifferentiated hours given over to the company of children' (10). Peter, a little boy intent on gaining his mother's attention, tugs 'at her arm, wanting her attention, wanting something, attacking her with his desire' (11). The repeated demands the child makes are an unwanted assault upon his mother, but when she turns her attention to him fully, her concentration 'startled him' (11).

Women writers indeed challenged many conventional literary assumptions. As Jenny Hartley puts it in Millions like Us: British Women's Fiction of the Second World War (1997), 'women writers were moving in the opposite direction to their male contemporaries' (9). The children in novels and short stories are viewed unsentimentally: the child feels and suffers as deeply as any adult. As we have seen, difficult and distressing subjects are touched on, such as rape in Macaulay's The World My Wilderness (1950), the loss of a sibling in At Mrs Lippincote's (1945) and alcoholism and addictive behaviour in Streatfeild's Saplings (1945).

\section{The Middlebrow}

As Mary Joannou suggests in her introduction to The History of Women's Writing, 1920-1945 (2013), women writers have 'a complex and often troubled relationship to modernity' (1) and to the modernist canon. 
Writing in their present time, they also partake in literary conversations with traditions from the past accommodating aspects of both in their work. The term 'middlebrow' is one ripe with complexity. There are a number of areas of contention including the boundaries delineating 'middle'-'high' and 'low' brow, problems related to canonicity and issues of gender and class. Joannou observes of the middlebrow that

its very existence is predicated on the terms "highbrow" and "lowbrow," and thus it 'assumes and perpetuates, rather than helping to question or to undermine, the kind of binary oppositions' that feminist critics of women's writing of the period might wish to erase.

'The permeability of the boundary between highbrow and middlebrow has ... been underestimated' (2), as Christoph Ehland and Cornelia Wächter write in their 'Introduction: "All Granite, Fog and Female Fiction" to Middlebrow and Gender: 1890-1945 (2016). They find much to discomfit and disturb the reader. 'Even though middlebrow fiction usually adheres to conspicuously affirmative structures of plot development', the narratives are often in a disintegrative state in their form and subject, raising 'disturbing issues' around Empire, class structure and the 'deterioration' of Victorian family ideals. One might also add that unsettling ideas about home and the child, the disintegration of homes and families at the behest of state-imposed regulations of conscription and evacuation are much in evidence in the interwar period and the decade afterwards.

For much of the twentieth century, critical opinion held middlebrow writing to be inimical to all that was best in the British literary tradition. As Q.D. Leavis puts it in Fiction and the Reading Public (1932), middlebrow fiction is the product of 'either a faked sensibility or else a suggestive insensitiveness to the life around them, a lack of discrimination and the functioning of a second-rate mind' (76). There has, however, been a reassessment of feminine middlebrow writing in a series of important critical works dating back to Nicola Beauman's A Very Great Profession: The Woman's Novel 1914-39 (1983), and including Nicola Humble's groundbreaking The Feminine Middlebrow Novel from 1920s to 1950s: Class, Domesticity and Bohemianism (2001). Humble's pioneering work recognizes that middlebrow fiction was 'uniquely designed to appeal to the changing identity and tastes' (11) of the middle class as it expanded and altered. Stressing the importance of the concept of the middlebrow in relation to women's literary production of the time, she makes the case that authors such as Lehmann, E.H. Young, Winifred Holtby, Taylor and Nancy Mitford played a crucial part in developing and reformulating new class and gender identities in this period of rapid change for both women and the middle classes, reshaping notions of the 


\section{Introduction}

home, social class, family and sexuality. Humble shows how the feminine middlebrow novel has a 'characteristic voice' and set of 'ideological assumptions' as well as 'a particular attitude to itself and its readers' (97). ${ }^{13}$ The relationship between the author and the women who were assumed to constitute the majority of readers of feminine middlebrow fiction written by women is important because a shared ideology and assumptions provide scope to extend, challenge and subvert accepted ideas. More recent works include Middlebrow Literary Cultures: The Battle of the Brows 1920-1960 edited by Erica Brown and Mary Grover (2012), Christoph Ehland and Cornelia Wächter's Middlebrow and Gender 1880-1945 (2016) and Kate MacDonald and Christopher Singer's Transitions in Middlebrow Writing: 1880-1930 (2015).

As I referred to above, the middlebrow also had an important role in the dissemination of new ideas about subjects of gender, class and also in the spread of popular versions of psychology, providing the reader with at least a passing familiarity with psychological concepts such as inhibition and repression, amongst others. Geraldine Coster's Psycho-Analysis for Normal People (1932) illustrates in its title the popular perception of psychoanalysis as a field for study by other than normal people. ${ }^{14}$ However, by the 1930s, as Q.D. Leavis says in Fiction and the Reading Public, 'the jargon of popular psychology is now at the writer's disposal' (259), and novels (such as those of Gilbert Frankau, according to Leavis) are 'so thickly studded with mention of inhibitions and the subconscious that it is hardly possible to find a page without one or both' (260). Leavis mocks 'the generalisations on Life, Love, Marriage, Sex, Woman etc., which fill the popular novel' (256), but this book will show the surprising dissemination and anticipation of complex theories and ideas through the medium of the middlebrow novel.

Whether they liked it or not, it was usually women in whose hands the everyday care of wartime children lay. Whether they were parents or involved in secondary roles such as, for example, volunteers in the evacuation programme, foster parents, members of the Women' Royal Voluntary Service (WRVS) canteen workers or serving in any one of a considerable number of largely unrecognized roles, the majority of the women writers I discuss were never far from a child when they put down their pen. For example, Adam, Peck, Lehmann, Margharita Laski, Godden and Taylor all had small children at the time, and Lovett, Mitford and others had some experience of evacuees within their homes or those of their families.

If the 'new commercial sphere' of 'homemaking' put 'woman and the home, and a whole panoply of connected issues, at the centre of national life' (10) in the inter-war period, then even with the 'unmaking', demolition or breaking up of homes in the Second World War, the feminine middlebrow writer locates the figure of the woman and very often the figure of the woman as mother, at the centre of national life. Good 
examples of women who kept the home together at a time of national crisis and uncertainty are the working-class mothers, Mrs Barton in Phyllis Bottome's London Pride and Mrs Malone in An Episode of Sparrows (1956). In children's fiction, Mrs Carey is the uniting force behind her family's success in Margaret Lovett's Family Pie, in which she is the 'family cook' (256). And with the figure of the mother, there is the child.

Many of these writers refer to an experience of wartime hardship and difficulty, situated in a domestic context with which the woman reader at the time of publication is likely to be familiar. Good examples are the struggle to maintain a pre-war house with wartime staff shortages as seen in Peck, House Bound (1942), and the effect of 'fatigue from the war' on a marriage, as Taylor describes this in 'Gravement Endomagé' (1954), as well as the familiar issues around evacuation dramatized in Barbara Noble, Doreen (1946), and Bottome, London Pride (1941).

Feminine middlebrow writing is rarely viewed in terms of psychoanalysis, as this is generally considered as more appropriate for 'highbrow' writing. However, despite the fact that they may have had little or no knowledge of psychoanalytic theory (or indeed psychoanalytic practice) and that some of the theories that I discuss might appear rather esoteric or erudite, symmetries between psychoanalysis and fiction sometimes occur in their work. This is because war had a terrible effect on childhoods and the middlebrow writer, equipped with her 'sensitive, inquiring intelligence' (Piette 4), was often better positioned than most to see the consequences.

As Katherine Cockin and Jago Morrison observe in their introduction to the Post-War British Literature Handbook (2010), 'Literature had a much more significant part to play in bearing witness to the traumatic experience of war and to mediating survivor guilt, than earlier critics were able to recognise' (4). In this book, I argue that middlebrow fiction had a significant part to play in providing a voice for writers' anxiety, as well as articulating the experience of the home front for the middle classes. Children's fiction (albeit, frequently written from a middle-class perspective) has the capacity to reassure, with images of fear managed and evil subverted. As a response to widespread feelings of anxiety after the First World War, psychoanalysis had acquired a significant role in offering guidance and explanation to those dealing with troubled children.

\section{Writing for Different Audiences}

In a break with critical tradition, I include novels written for adults and for children because some authors wrote for both audiences, including Streatfeild, Godden, Peck and Taylor. Although children's fiction naturally raises questions about audience appropriacy and subject matter, I show that the physical effects of fear and anxiety are portrayed with frankness and realism and are written in language similar to that seen 


\section{4}

in contemporaneous child psychoanalytic theory. The adventure stories that I analyse offer vicarious excitement and opportunities for bravery, all features common to children's literature, but here I situate the selected novels in a wider debate about the effect of war on the child and the writer that finds echoes and pre-echoes of psychoanalytic theory.

The field of children's literature criticism has been described as 'unruly' and 'hard to delimit', and critics (including myself) have found it challenging to define even the wide parameters of subject and audience. It is suggested that children's literature might comprise texts written for a distinct audience of children, but Marah Gubar, writing in 'On Not Defining Children's Literature' (2011), warns against such an approach. She divides the critical ground between 'definers' and 'antidefiners', locating her work in the middle, where, with some relief, she finds 'the vast majority of scholars' are finding no 'real impediment' to their work in the lack of an 'overarching definition' (210). Others, including Perry Nodelman and Myles McDowell, have pointed to a muddy middle ground between the extremes of definers and antidefiners. McDowell's famous analogy of spilt orange and green paint demonstrates this but also illustrates, as Gubar points out, that 'he and other definers go too far' when they 'insist' that it is possible to 'single out 'defining characteristics" that set genuine children's texts apart as belonging to their own genre. ${ }^{15}$ Instead, Gubar commends her readers to turn to Wittgenstein. As 'philosophers of language remind us' Gubar says, 'the idea that all viable concepts have definitions is profoundly controversial' (212). Wittgenstein instead points helpfully, for our purpose, to the word 'games' to 'illustrate how diverse an array of things' it encompasses. Gubar finds Wittgenstein's idea of the 'family resemblance' appealing and enabling. It 'enables us to stake out a middle ground' rather than pursing either definers or antidefiners. It is not necessary to 'throw out the concept of children's literature' nor to 'unearth a common trait exhibited by all (and only) children's texts'. The 'impossible' category to which Jacqueline Rose referred in The Case of Peter Pan; or, The Impossibility of Children's Fiction (1984) can instead be 'complex and capacious' as well as 'unstable' and 'fuzzy at the edges'. Thus, if one views this category as akin to Mary Poppins's famous carpet bag, as seen in Walt Disney's 1964 version of P.L. Travers's book, it leaves opportunity for much to be discovered within.

This book recognises a further important division within critical work on children's literature, primarily divided along lines of approach: the first relates to the children's literary text as a work of literature; the second to the perceived educational merit of the text and the response of the child reader. For example, the evacuated child might find merit in a novel about children facing danger alone, whilst the sensitive and well-written account of a child's discovery of her own femininity in Lovett's Family Pie has literary merit. I have adopted a literary critical approach to 
enable the selected children's texts to be considered on similar terms to those applied to adult fiction. A work that attempts to straddle the adult/ children's fiction divide is Mary Cadogan and Patricia Craig's Women and Children First: The Fiction of Two World Wars (1978). However, Cadogan and Craig are largely concerned with 'the serious novelists' (202) who 'affirm values without needing to instruct them' (202) and who were 'slightly at odds with the mood of the time' (202). Their research was conducted before similar features were identified with what Nicola Humble calls the middlebrow writer's 'negotiation of new class and gender identities' (101) and with the need to 're-cast' (101) the terms of the intellectual and cultural 'battle' between the high- and lowbrows (101). As Erica Brown and Mary Grover observe, the middlebrow is 'a product of contested and precarious assertions of cultural authority' (2).

Taken as a whole, the focus of this study is on literary criticism and the application of psychoanalytic theory, to which end there is a blurring of the distinction between adult and children's fiction, as some works (for example, Godden's An Episode of Sparrows (1955) can be identified as young adult fiction. None of my selected texts are written for very young children, and adult themes are discussed in some of the works written for children: for example, Lovett's Family Pie (1947) discusses brutal treatment and trauma, and some aspects of Streatfeild's The House in Cornwall are troubling. The category of 'Young Adult' fiction may at first glance appear helpful. At the time of first publication, the legal age for a child to leave school was fourteen. However, if it is unhelpful to define children's literature as other than linked by familial resemblances, can the same not also be said of the further subdivision of children's literary criticism into age-specific categories? Surely, the 'fuzzy edges' of childhood are never more important than where the child is considered legally at the cusp of something else? The 'otherness' of the child/young adult implied reader and its relationship to the adult writer will be discussed further in Chapter 1, but I raise here these important questions as a precursor to my study.

I have selected three children's adventure novels for the focus of my first chapter. These contain references to growing up and to adult themes, and one of the 'children' is about to undertake national service, so there are grounds for considering this a work for older children. However, citing Karen Coats's 'Young Adult Literature: Growing Up, In Theory' in the 2011 Handbook of Research on Children's and Young Adult Literature, Coats identifies a number of relevant criteria for separating 'preadolescent' from 'young adult' fiction (322). Firstly, she argues there are publisher-indicated age ranges, based on a study of format, likely appeal, length, vocabulary and how sophisticated the subject matter may be. Most of the novels I discuss are relatively unsophisticated in vocabulary and subject matter; Cornwall is a Dragon Book marked ' $12-15$ 'on the cover (in the 1968 edition to which I refer), 
and both Family Pie and Dinah have illustrations, all of which I argue is indicative of a publisher who anticipates a preadolescent rather than a young adult readership. Coats cites 'pragmatic considerations' too. For example, her colleagues Anita Tarr and Roberta Seelinger Trites give 'sex as a key determining factor', hence, 'if a book has sex in it, it's YA, if it doesn't, it's preadolescent' (322). On this basis too, I retain the term preadolsecent as none of my books refer explicitly to sex. Thirdly, Coats indicates her own preference to be 'more ideological', centered on the presence of a 'closed' or 'open' moral universe. A closed moral universe has 'a plot line that features punishment for the wicked and reward for the good'. Once again, all three novels feature just such a closed moral universe. Like Coats, I recognise the challenge of identifying the 'clear demarcation line' between children's literature (and I propose to include preadolescent fiction for the avoidance of doubt). Therefore, I refer to the selected adventure novels as children's fiction in Chapter 1.

Noel Streatfeild writes for both audiences in her own name, reserving the pseudonym 'Susan Scarlett' for romantic, lighter fiction such as Murder While You Work (1944) and Clothes Pegs (1939). Writing for adults and children was not perceived as being so different as to warrant the use of a pseudonym. As Kirstie Taylor observes in her introduction to the 2008 Greyladies edition of Murder While You Work (1944), there was no shame 'in producing ideal books for reading in air-raid shelters' (v). Streatfeild's two audiences were encouraged to give up unwanted books for pulping as part of the war effort. John Lehmann comments in Penguin New Writing (1947) that one 'fire at a great wholesaler's warehouse on a December's night in 1940' did 'a notable service' in disposing of 'hundreds of thousands of third-rate books' (Lehmann 7).

As Jean Wood Garrison observes in her unpublished MA thesis, 'A Comparison of Selected Factors in Children's Realistic Fiction having War-related Plots Published in England and the United States During World Wars I and II' (Temple University 1981), many books were destroyed during the Blitz. Garrison cites 'paper shortage and lack of time' as limiting the 'output' of 'many established authors' (54). In spite of this, many women were taking comfort from the process of writing, whether fiction, letters or diaries. Naomi Mitchison says of her 100,000,000 words of wartime diary writing that 'maybe one needs to cry on an invisible shoulder'. She remarks on 22 June 1941: 'Of course, one realizes that Mass-Obs is a kind of God-Figure - one confesses, one is taken an interest in, encouraged' (Mitchison 154) and asks 'will Mass-Obs supercede psychiatry?' (154). ${ }^{16}$ For others, writing was key to financial security.

All my writers are, to a greater or lesser degree, connected by links of correspondence and support. ${ }^{17}$ In Chapter 6, I show how interconnected were the lives of these women by reference to their letters and known connections and through family, friends and lovers. Some of my 
authors knew each other well enough to sleep on each other's floors or sofas (as in the case of Storm Jameson and Noel Streatfeild), or to write congratulatory letters on a new publication (as Mary Treadgold did to Lehmann). Letters might include criticism (as in the case of Stevie Smith and Lehmann) or commiseration, as in the correspondence between Lehmann and Streatfeild, Bowen and Macaulay. Similar patterns are seen in the correspondence of Barbara Pym, Taylor and Bowen. Laski and Betty Miller were also good friends, and Miller and Lehmann were close friends and regular correspondents. ${ }^{18}$ Wartime experiences and personal difficulties encouraged closeness through written correspondence, as did involvement with political and social welfare organizations as in the cases of Taylor, Streatfeild and Adam. I include a map of the connections between my writers in Chapter 6, 'Literary Mothers'.

As a result of the new duties and obligations undertaken by women, 'war service' inevitably penetrated into fiction, as did 'the consciousness of writing history' (Hartley 10). For those whose fiction was published, financial independence was a welcome and powerful incentive for the writer to work. As Virginia Woolf observes in 'Professions for Women', a paper read to The Women's Service League, 'I made one pound ten and six by my first review' and 'I grew ambitious. ... I must have a motor car' (Woolf, 'Professions for Women' 151). And the Postscript to Bowen's The Demon Lover and Other Stories (1945) recognizes that all the stories were 'written for the magazines or papers in which they originally appeared'. Bowen states: 'I did not write any story that I was not asked for' (190), recognizing the practical (and financial) purpose of her writing. This was also the case for others; Lehmann and Streatfeild. There is a recognized audience and a demand for middlebrow fiction to which the writer responds. Streatfeild notes in the Diary of the Blitz on 20 September 1940 that: 'I can't write about country rectories, and help evacuate posts all at the same time'. Streatfeild found the peaceful rectory hard to imagine as she continued her work as an air raid warden, but she finished this romantic novel on September 26 (presumed to be one written under the pseudonym Susan Scarlett) so that her readers had something 'sweetly pretty' to read. Writing supports not only Streatfeild but also pays for her housekeeper, Millie, and her secretary, Joan, both of whose voices are vivid and characterfully depicted. Her writing is central to this book; the best of this is sensitive and moving and alive to the effects of war upon the psyche.

\section{Child Anxiety}

War and the fear of air raids makes one feel like a child, encouraging an empathy with the child's innate vulnerability and powerlessness. ${ }^{19}$ When writers adopt roles that impinge upon the child, whether as mother, teacher, foster mother or social worker, it gives the reader licence to 


\section{Introduction}

investigate (through their fiction) fears and anxieties that bring the writer close to the child's experience of a larger adult power. Aiding others (and especially children) is a kind of self-defence. As Edward Glover wrote in The Psychology of Fear and Courage (August 1940); 'those of you who have little children will understand what I mean when I say that to help and support others is not only good for them, it is good for you' (25). Writing about (and sometimes writing for) children may offer solace or respite 'in times of danger' (24). As the writers explore feelings of fear, distress and powerlessness through the intermediary of a fictional child, they may find relief. As Margarida Morgado recognizes in 'A Loss Beyond Imagining: Child Disappearance in Fiction' (2002), sometimes the figure of the child is a 'production of adults interested mainly in reliving their pasts or using the child to articulate fears and wishes' (247).

After the repercussions of the First World War, psychoanalysis became popular as a treatment of anxiety, as well as explaining the importance of early influences on later life. In a letter of apology to her brother John, Lehmann describes

a cry far back, deep-rooted panic and horror rose up in me when you were shouting; it wasn't only your shouting at me, it was Daddy shouting at Mother which is one of the deepest traumatic memories of my childhood. Probably you never witnessed it, but I did, more than once.

(Hastings 326-7) 20

Anxiety, as a reaction to traumatic events, is often present in oneself or felt for one's loved ones; and these feelings left the writer yearning for a key to make sense of their fears (and those of others) as reassurance that they were not going mad. Psychoanalysis is appealing in wartime because it offers a methodology and a way to respond to thoughts and feelings and an alternative to feelings of inadequacy at a perceived failure to manage one's emotions. As Hartley observes, again in Millions Like Us, 'suppression became a characteristic mode for women' (Hartley 7). Suppressing their deepest feelings, writers seeking an explanation for, or at least another way of looking at, war so that they could survive it emotionally. ${ }^{21}$

\section{Writing for Survival}

Having lost her mother when she was thirteen, Virginia Woolf felt that until the forties, 'the presence of my mother obsessed me. I could hear her voice, see her, imagine what she would do or say' ('Moments of Being' 92), but when she wrote To The Lighthouse (1927), she 'ceased to be obsessed with her' (93). Woolf explains: 'I suppose that I did for myself what psycho-analysts do for their patients. I expressed some very 
long felt and very deeply felt emotion. And in expressing it I explained it and then laid it to rest.' 'Sketch of the Past' was written in 1939 and demonstrates how writing can operate as a kind of defensive mechanism against extreme anxiety. Three years later, Gordon Allport's The Use of Personal Documents in Psychological Science (1942) supports Woolf's theory (and I read 'scriptotherapy' into a number of the novels I discuss) and explains why writers sometimes unwittingly expose sensitivity or personal information in personal writing. As Allport puts it, 'catharsis is the underlying motive in the production of personal documents', while importantly, 'through writing one secures relief from mental tension' (71). Bowen, writing her 'Postscript' to 'The Demon Lover' and Other Stories in 1945, also acknowledges the therapeutic effect of writing: 'the stimulus of being asked for a story and the compulsion created by having promised to write one were good - I mean they acted as releases' (190). She adds that 'Each time I sat down to write a story I opened a door', which acted to relieve 'the pressure' that was holding back the flood of 'ideas, images, emotions' which then came out 'with force and rapidity, sometimes violence' (190 and 191). She acknowledges that 'these impulsive movements of fantasy are by-products of the non-impulsive major routine of war' when 'there was an element of chanciness about everything' (195). 'Fantasy' and the idea of a creative 'pressure' exerted against a previously unrecognized 'door' may also suggest how writing was connected to the unconscious: if anxiety was widespread and the past has 'a load of feeling' to be 'discharged' at 'the cost of no little pain', then surely these writings are close to writing as therapy, as Allport observed in 1942. Women authors may unintentionally reflect and release the feelings of anxiety and 'pressure' described by Bowen, in a process similar to what Freud called sublimation. Sublimation was, in Freudian terms, related to the redirection of repressed sexual feelings. However, in wartime, as I discuss in Chapter 1 and elsewhere in this book, there is a suppression of non-sexual feelings of fear, anxiety and distress deemed in a wartime setting to be unpatriotic and shameful. In the writer, these feelings may seep out in writing in an acceptable form, such as the voice of a child or through the inintentional use of writing as therapy, as described by Allport.

\section{Narrative Theory: Containing the Child}

The women's middlebrow novel often appears stylistically conventional and uninteresting. Q.D. Leavis remarks in Fiction and the Reading Public (1932) that 'the reading capacity of various ages may be gauged by the demands made on each by its popular fiction', and she goes on to argue that 'the reading capacity of the general public ... has never been so low as at the present time' (231). But in some cases, there is a greater complexity of form and literary structure than Leavis allows. These novels 


\section{0}

also help to illustrate how far Britain's wartime culture and anxieties remains fixated on childhood. I employ a methodology of close reading and draw upon a number of difficult and complex psychoanalytic theories in support of my key proposal; that the figure of the wartime child in women's fiction of the period becomes a surrogate for the writer herself, or for her suppressed feelings of anxiety.

As Michel Foucault writes in 'What is an Author?' in 1969, there is a longstanding connection between writing, the writer and death. 'Our culture has metamorphosed this idea of narrative, or writing, as something designed to ward off death.' He identifies two thematic strands, both of which are of interest to this study. Firstly, there is a desire to leave a legacy in times of crisis. Foucault argues that in the past, the bravery of the hero described in epic poetry accepted his 'assumed death' because his death is 'redeemed' by the narrative, which will outlive its writer and the hero. Secondly, using the example of Scheherazde, narrative acts as an agent to 'forestall death' by telling stories throughout the night to delay 'the day of reckoning that would silence the narrator' (206) forever.

Where Foucauldian narrative operates to ward off death, this book extends the agency of narrative through the talismanic figure of the wartime child. Stephen Spender (himself a visitor to Anna Freud and Dorothy Burlingham's wartime residential nursery) wrote in the Foreword to The Still Centre (1939) that 'The violence of the times we are living in, the necessity of sweeping and general and immediate action, tends to dwarf the experience of the individual' (10). In one response to the ungentle mechanics of war, women writers use the fictional wartime child to vocalize anxiety, and in so doing, they will be seen to anticipate or match the work of wartime and later psychoanalysis.

The methodology chosen for this study is based on close reading, informed by psychoanalytic theory. As James Wood writes in How Fiction Works (2008), 'the novel becomes the great analyst of unconscious motive' as 'the character is released from having to voice his motives' and 'the reader becomes the hermeneut, looking between the lines for the actual motive' (113). ${ }^{22}$ Foucault argues that critical theory now asks of the fictional text 'From where does it come, who wrote it, when, under what circumstances, or beginning with what design?' (215), and these very questions inform my own thinking. Materials outside the text are key to my interrogation of 'the solid and fundamental unit of the author and the work'.

As Foucault says, 'the author provides the basis for explaining not only the presence of certain events in a work, but also their transformations, distortions, and diverse modifications' (214), and this work looks at original source material for evidence of 'his biography, the determination of his individual perspective, the analysis of his social position, and the revelation of his basic design'. The reader is provided with letters, essays and biographical details and decodes the messages of the text, rewarded with a deeper understanding of the author's meaning. Taylor 
conceals and disguises details within her narrative, such as the infidelity of Roddy Davenport in At Mrs Lippincote's (1945). The reader sees Roddy's 'look of anticipation' on going out alone (127) and is rewarded with prior knowledge of his affair and also recognizes that Julia (his wife) has chosen to ignore the affair, as 'she turned from the window, depressed' (127). The literary texts demand and reward the reader's effort in locating this hidden meaning. Taylor may also be 'writing out' her feelings about her own husband's infidelities, indicating the unconscious need to put feelings into words.

As Nicola Humble puts it in 'The Feminine Middlebrow Novel' (99), middlebrow writing is 'the place where highbrow and lowbrow distinctions break down', and it has a 'characteristic voice, a set of ideological assumptions' and 'a particular attitude to itself and its readers' (99). By writing within known conventions, the author can investigate and subtly challenge the expectations of its readers. However, I dispute the view that 'a piece of literature can be adequately interpreted by understanding the intentions of its author' (Mikics 157) as unconscious influences are also at work. According to Andrew Bennett and Nicholas Royle's An Introduction to Literature, Criticism and Theory (1997), with the advent of psychoanalysis it becomes 'difficult if not impossible to suppose that intention can ever be pure and unambiguous' (Bennett 22). Fiction sometimes exposes unconscious fears or frustrations, so the mediating influence of unconscious feelings needs to be acknowledged.

The middlebrow novel is often based around a primarily domestic setting, and has been criticized for a want of stylistic complexity. However, this can demonstrate remarkable flexibility of style and language. As one example, Lehmann's 'A Dream of Winter' describes a woman suffering from flu at the time of the 1941-2 winter, recorded as the coldest winter of the twentieth century (Lejenas 271). There is a sense of blurring and unreality that renders the symptoms of the narrator's illness a part of the narrative itself. Lehmann's narrative is sophisticated, using the free indirect style to create a sense of her illness. As her temperature soars and peaks, the narrative follows the disjointedness of fever, and physical and textual gaps appear in the text as she 'sank into burning sleep' and again 'she closed her eyes' and was 'roused by a rap on the pane'. The gaps represent the periods of her unconsciousness as she slips between wakefulness and sleep, unable to grasp either. These 'gaps' also represent the intrusion of her illness into the narrative, as Lehmann leaves the reader to interpret the 'unspoken' within the narrative. Lehmann's perspective is unusual. As Woolf writes in 'On Being Ill' (1926), 'those great wars which the body wages with the mind a slave to it, in the solitude of the bedroom against the assault of fever or the onset of melancholia, are neglected' (4), as illness defies language. Thus, when illness takes a narrative form, this is marked by uncertain spaces: evasions, elisions and gaps that raise questions for the reader, and within which the unconscious may be found. 